\title{
Article
}

Arq Neuropsiquiatr 2010;68(2):242-245

\section{Temperature variation in the 24 hours before the initial symptoms of stroke}

\author{
Fernando Morgadinho Santos Coelho', \\ Bento Fortunato Cardoso dos Santos ${ }^{1}$, Miguel Cendoroglo Neto', \\ Luis Fernando Lisboa', Adriana Serra Cypriano', \\ Tania Oliveira Lopes', Marina Jorge de Miranda², Ana Maria H. Ávila², \\ Jonas Bordin Alonso², Hilton Siqueira Pinto²
}

\begin{abstract}
A few studies have performed to evaluate the temperature variation influences over on the stroke rates in Brazil. Method: 176 medical records of inpatients were analyzed after having had a stroke between 2004 and 2006 at Hospital Israelita Albert Einstein. The temperature preceding the occurrence of the symptoms was recorded, as well as the temperature 6 , 12 and 24 hours before the symptoms in 6 different weather substations, closest to their houses in São Paulo. Results: Strokes occurred more frequently after a variation of $3^{\circ} \mathrm{C}$ between 6 and 24 hours before the symptoms. There were most hospitalizations between $23-24^{\circ} \mathrm{C}$. Conclusion: Incidence of stroke on these patients was increased after a variation of $3^{\circ}$ Celsius within 24 hours before the ictus. The temperature variations could be an important factor in the occurrence of strokes in this population.
\end{abstract}

Key words: stroke, temperature, cardiovascular risk, seasonal.

Variação da temperatura nas $\mathbf{2 4}$ horas anteriores aos sintomas iniciais do acidente vascular cerebral

\section{RESUMO}

Poucos trabalhos têm estudado a variação sazonal e de temperatura em acidente vascular cerebral (AVC) no Brasil. Método: Foram analisados 176 registros de pacientes com AVC no Hospital Israelita Albert Einstein entre 2004 e 2006. Foram anotadas as temperaturas ambientes do início dos sintomas, bem como as temperaturas de 6, 12 e 24 horas antes dos sintomas, em 6 diferentes subestações metereológicas mais próximas da casa do paciente em São Paulo. Resultados: Houve aumento da incidência do AVC com a variação de $3^{\circ} \mathrm{C}$ entre 6 e 24 horas antes do início dos sintomas. Houve um pico de internação entre 23$24^{\circ} \mathrm{C}$. Conclusão: A variação de temperatura de $3^{\circ} \mathrm{C}$ nas 24 horas que antecederam o início dos sintomas pode ter sido um fator importante na ocorrência do AVC.

Palavras-chave: acidente vascular cerebral, temperatura, risco cardiovascular, sazonal.

\section{Correspondence}

Fernando Morgadinho Santos Coelho

Avenida Albert Einstein 677

$1^{\circ} \mathrm{SS}$ - Prática Médica

05651-901 São Paulo SP - Brasil

E-mail: fernandomorgadinho@hotmail.com

or fmscoelho@einstein.br

Received 1 August 2009

Received in final form 22 October 2009

Accepted 3 November 2009
The correlation between strokes and seasonal variations have been studied in various places ${ }^{1-8}$. Some studies around the world have reported an increase of incidence, mortality, and stroke hospitalization during the coldest months of winter.

The authors suggest that the temperature variations may trigger responses of vasoconstriction with increase in cardiovascular events. However, the understanding of the relation between changes of weather and cardiovascular events is limited ${ }^{9-13}$. The variation of temperatures before the occurrence of ictus has not been frequently observed. The change in temperature before a stroke could has play a more important role than the season it self. Authors show that the incidence of hemorrhagic stroke (HS) was higher on those days during which the temperature varied significantly ${ }^{12}$. 
A few studies have been performed to evaluate seasonal and temperature variation in the Southern Hemisphere ${ }^{13,14}$. Since Brazil is a tropical country, we believe that the seasons have less influence on the incidence of cerebral vascular disease than thermal changes. It is known that the seasons in tropical countries are not as distinctive as in the temperate climate countries. Therefore, it becomes difficult to compare the influence of the environmental aspects on different parts of the world ${ }^{14}$. The effects of the temperature variation on risk factors in stroke incidence have not been easily shown.

Especially in a great metropolitan area as Sao Paulo, there is a substantial heterogeneity of temperature depending on the part of the city. This piece information stresses the importance of checking the local temperatures depending on which part of the city each patient lives or works.

The goal of this study is to describe the temperature variation during the 24 hours before the occurrence of the stroke such the measurement was recorded by weather substations in the city, depending on their proximity to the patient's location.

The purpose of this study is to analyze the temperature variation during the 24 hours before the beginning of symptoms of stroke on the inpatients at Hospital Albert Einstein between August 2004 and December 2006.

\section{METHOD}

This is a retrospective study that has used data from the medical records of inpatients with stroke, admitted to the Hospital Israelita Albert Einstein. All patients were monitored by the stroke protocol between August 2004 and December 2006. The study was approved by Hospitals Ethics Committee under number 411-08.
Since July 2004 Hospital Israelita Albert Einstein has haven a stroke team. (Joint Commission Certificated Stroke Center - 2007 May).

A total of 176 medical records of inpatients have been reviewed with cerebral vascular disease. The patients were separated into groups according to the aetiology of the ischemic stroke (149 patients) or hemorrhagic stroke (27 patients). Patients with ischemic strokes were subdivided in thrombotic stroke (101 patients) and embolic stroke (48 patients) according to TOAST criteria.

\section{Inclusion criteria}

All patients between 50 and 80 years old who had acute stroke confirmed. Exclusion criteria: All patients younger than 50 years old and older than 80 years old and whose symptoms began while sleeping.

The temperature at the beginning of the symptoms on the date of hospitalisation was noted, as well as the temperature 6,12 and 24 hours before the initial symptoms in 6 different weather substations in the city, depending on their proximity to the patient's address by team of CEPAGRI (Centre for Weather and Climate Research).

Continuous variable data were expressed as number of hospitalizations (n) mean value, standard deviation (STD Dev) median, lower quartile (Q1), upper quartile (Q3), minimum and maximum values. Categorical variables were expressed as frequency.

The number of inpatients was presented after applying the Poisson random variables, where each hospitalisation was assumed to be a function of temperature, year and month. The Generalized Additive Model (GAM) was used to fit both a reduced categorical model and a nonparametric spline model.

Table. Number of hospitalizations of patients with stroke.

\begin{tabular}{|c|c|c|c|c|c|c|c|c|c|c|}
\hline \multirow[b]{2}{*}{ Month } & \multicolumn{3}{|c|}{ Thrombotic } & \multicolumn{3}{|c|}{ Haemorrhagic } & \multicolumn{3}{|c|}{ Embolic } & \multirow[b]{2}{*}{ Total } \\
\hline & 2004 & 2005 & 2006 & 2004 & 2005 & 2006 & 2004 & 2005 & 2006 & \\
\hline Jan & & 1 & 6 & & & & & 3 & 2 & 12 \\
\hline Feb & & 5 & 3 & & & & & 1 & 2 & 11 \\
\hline Mar & & 7 & 5 & & 3 & 4 & & 1 & 9 & 29 \\
\hline Apr & & 6 & 2 & & 1 & 1 & & 3 & 4 & 17 \\
\hline May & & 6 & 6 & & & 4 & & & 2 & 18 \\
\hline Jun & & & 3 & & 3 & & & & 2 & 8 \\
\hline Jul & & 6 & 6 & & 2 & & 1 & 1 & 1 & 17 \\
\hline Aug & 1 & 10 & 4 & & & & & 3 & & 18 \\
\hline Sep & & 1 & 3 & 2 & 1 & 2 & 2 & 1 & 2 & 14 \\
\hline Oct & 3 & 3 & 2 & 3 & & & 2 & 1 & & 14 \\
\hline Nov & 6 & & & & & & & 1 & & 7 \\
\hline Dec & 3 & 3 & & & 1 & & 3 & 1 & & 11 \\
\hline Total & 13 & 48 & 40 & 5 & 11 & 11 & 8 & 16 & 24 & 176 \\
\hline
\end{tabular}




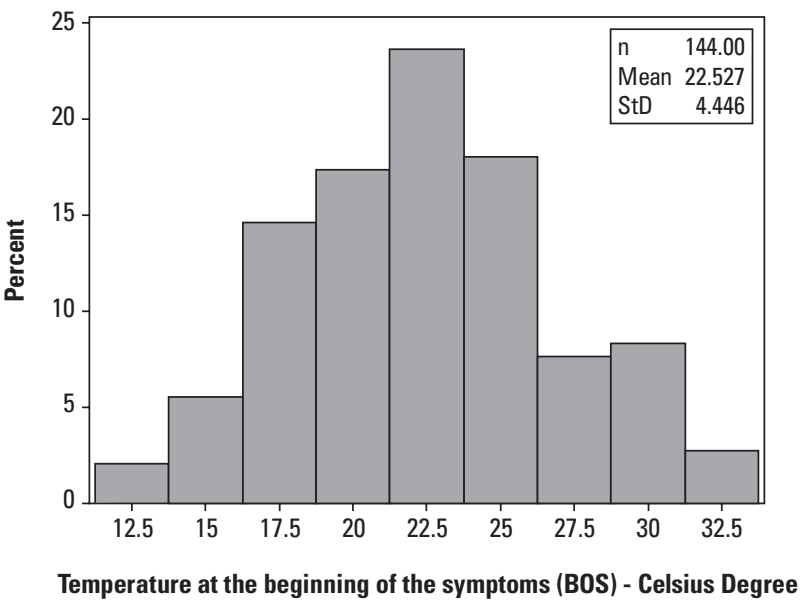

Figure. Histogram of temperature at the beginning of symptoms before the beginning of symptoms.

\section{RESULTS}

There were no differences in the numbers of hospitalisations among types of stroke after analysis of the seasonal factors. There was an increase of stroke inpatients in March (Summer-Autumn) (Table).

The numbers of hospitalisations were low bellow the temperature of $20^{\circ} \mathrm{C}$, increasing until it reached a maximum between $23-24^{\circ} \mathrm{C}$, and decreasing again. The hospitalisations after ischemic and haemorrhagic strokes were more frequent at an average temperature that is more prevalent temperature at São Paulo $\left(22.52 \pm 4.44^{\circ} \mathrm{C}\right)$ (Figure).

\section{DISCUSSION}

The highest prevalence of cerebral vascular disease hospitalisations occurred in March, a period that corresponds to the end of Summer in Brazil. This data differs from other studies that show a higher predominance of cerebral vascular disease during the Winter. Our study demonstrates that the variation of $3^{\circ} \mathrm{C}$, measured close to the patient's address, during 24 hours before the occurrence of a stroke was an important factor for these patients in São Paulo. There was an increase in the hospitalization of patients with stroke between $23-24^{\circ} \mathrm{C}$, which is the range most common temperature of the city. However, the differences between environmental and room temperature exposition could be a bias for our study. On the other hand, the association among daily variation of temperature in the environment, pollution and cardiovascular mortality has been demonstrated in epidemiological studies ${ }^{15-18}$. An interesting study found out some factors that have increased the cardiovascular risk, such as the variation of environmental temperature, drier air, upper respiratory infections, grass pollen, $\mathrm{SO} 2$, and particulate air pollution ${ }^{19}$.

It is known that the variation of temperature plays an important role in risk factors of cardiovascular diseases, such as respiratory infections, concentration of particulate air and agglomeration of people with a high possibility of having had contact with the influenza virus, for example. Likewise, another interesting study has shown that a decrease in air temperature over a few days is associated with an increase among $C$-reactive protein, interleukin-6, and fibrinogen with increased cardiovascular risk ${ }^{20}$.

Previous studies carried out in England have analyzed the variation of temperature before the occurrence of a stroke and it noted five days between the decreased in temperature and the incidence of the stroke $\mathrm{e}^{21-23}$.

The new and interesting finding of our study is that almost all of our patients started to show the symptoms during a comfortable range of temperature $\left(23-24^{\circ} \mathrm{C}\right)$ after a variation of $3^{\circ} \mathrm{C}$.

In this way, a new study has reported that the daily average of $\mathrm{HS}$ for the group aged $<65$ increased by $15 \%$ and $12 \%$ for a $1{ }^{\circ} \mathrm{C}$ increase in daily maximum temperature and minimum temperature in the Summer and that the daily average of IS for the group aged $\geq 65$ decreased by $3 \%$ for a $1^{\circ} \mathrm{C}$ increase in daily maximum temperature in the Winter, after the adjustment of confounding factors $^{13}$. Such study has not analyzed in detail the 24 hours prior to the event and the authors didn't use the temperature that was closest to the patient's location. Unfortunately, the general analysis of the temperature variation can contain mistakes.

The bottom line is that temperature variations were an important factor for the occurrence of Stroke and that the events were more frequent after the normalization of the local temperature during the 24 hours before it occurred.

ACKNOWLEDGMENTS - We thank the patients and staff members Reynaldo Brandt, Eliova Zukerman, Pedro Paulo Porto, Paulo Hélio Monzillo, Pedro Camilo de Almeida Pimentel, Roberto Naun Morgulis and Alexandre Pieri for neurological support.

\section{REFERENCES}

1. Wang Y, Levi CR, Attia JR, et al. Seasonal variation in stroke in the Hunter Region. Australia A 5-year hospital-based study, 1995-2000. Stroke 2003;34: 1144-1150

2. Laaidi K, Minier D,Osseby GV, et al. Seasonal variation in strokes incidence and the influence of the meteorological conditions. Rev Neurol 2004;160:321-330.

3. Anlar O, Tombul T, Unal O, Kayan M. Seasonal and environmental temperature variation in the occurrence of ischemic strokes and intracerebral hemorrhages in a Turkish adult population. Int J Neurosci 2002;112:959-963.

4. Shinkawa A, Ueda K, Hasuo Y, Kiyohara Y, Fujishima M. Seasonal variation in stroke incidence in Hisayama, Japan. Stroke 1990;21:1262-1267.

5. Sobel E, Zhang ZX, Alter M, et al. Stroke in the Lehigh Valley: seasonal variation in incidence rates. Stroke 1987;18:38-42.

6. Piver WT, Ando M, Ye F, Portier CJ. Temperature and air pollution as risk factors for heat stroke in Tokyo, July and August 1980-1995. Environ Health Perspect 1999;107:11-16.

7. Oberg AL, Ferguson JA, McIntyre LM, Horner RD. Incidence of stroke and season of the year: evidence of an association. Am J Epidemiol 2000;152:558-564.

8. Field TS, Green TL, Roy K, Pedersen J, Hill MD. Trends in hospital admission for stroke in Calgary. Can J Neurol Sci 2004:31:387-393. 
9. Khan IA, Joy KP. Seasonal and daily variations in hypothalamic monoamine levels and monoamine oxidase activity in the Teleost Channa Punctatus (Bloch). Chronobiol Int 1988;5:311-316.

10. Baumgartl H,Heinrich U,Lubbers DW. Oxygen supply of the blood-free perfused guinea-pig brain in normo- and hypothermia measured by the local distribution of oxygen pressure. Pflugers Arch 1989:414:228-234.

11. Leppaluoto J, Paakkonen T, Korhonen I,Hassi J. Pituitary and autonomic responses to cold exposures in man. Acta Physiol Scand 2005;184:255-264.

12. Ohwaki K, Yano E, Murakami H, Nagashima H, Nakagomi T. Meteorological factors and the onset of hypertensive intracerebral hemorrhage. Int J Biometeorol 2004;49:86-90.

13. Wang $X Y$, Barnett $A G, H u$ W, Tong $S$. Temperature variation and emergency hospital admiss for stroke in Brisbane, Australia, 1996-2005. Int J Biometeorol 2009 [Epub ahead of print].

14. Alonso WJ, Viboud C, Simonsen L, et al. Seasonality of Influenza in Brazil: a traveling wave from the Amazon to the Subtropics. Am J Epidemiol 2007;165:1434-1442.

15. Ostro B, Chestnut L, Vichit-Vadakan N, Laixuthai A. The impact of particulate matter on daily mortality in Bangkok, Thailand. J Air Waste Manag Assoc 1999;49:100-107.

16. Samet JM, Dominici F, Curriero FC, Coursac I, Zeger SL. Fine particulate air pollution and mortality in 20 US cities, 1987-1994. N Engl J Med 2000;343:1742-1749.
17. Katsouyanni K, Touloumi G, Samoli E, et al. Confounding and effect modification in the short-term effects of ambient particles on total mortality: results from 29 European cities within the APHEA2 project. Epidemiology 2001 12:521-531.

18. Pope A. Epidemiology of fine particulate air pollution and human health: biologic mechanisms and who's at risk? Environ Health Erspect 2000; 108(Suppl 4): S713-S724.

19. Low RB, Bielory L, Qureshi Al, et al. The relation of stroke admissions to recent weather, airborne allergens, air pollution, seasons, upper respiratory infections, and asthma incidence, September 11, 2001, and Day of the Week. Stroke 2006;37:951-957.

20. Schneider A, Panagiotakos D, Picciotto S, et al AIRGENE Study Group. Air temperature and inflammatory responses in myocardial infarction survivors. Epidemiology 2008;19:391-400.

21. Donaldson GC, Keatinge WR. Mortality related to cold weather in elderly people in southeast England, 1979-94. BMJ 1997;315:1055-1056.

22. Kyobutungi C, Grau A, Stieglbauer G, Becher H. Absolute temperature, temperature changes and stroke risk: a case-crossover study. Eur J Epidemio 2005;20:693-698.

23. Yun-Chul H, Joung-Ho R, Jong-Tae L, Eun-Hee H, Ho-Jang K, Ho K. Ischemic stroke associated with decrease in temperature. Epidemiology 2003;14 473-478. 